Falah: Jurnal Ekonomi Syariah

(p)ISSN: 2502-3918; (e)ISSN: 2502-7825

Vol 4, No 2 (Agustus 2019), pp.119-132

DOI: https://doi.org/10.22219/jes.v4i2.9870

\title{
Pengaruh Islamic Social Reporting terhadap Profitabilitas (Return on Asset dan Return on Equity) Pada Bank Umum Syariah di Indonesia
}

\author{
Ana Santika \\ Program Studi Ekonomi Syariah, \\ Pascasarjana Universitas Islam Negeri Raden Intan Lampung \\ Email: anasantika50@gmail.com
}

\begin{abstract}
The act of accuracy and prudence is very important in the company, because are the factor that determines the sustainability of companies such as banking. This study aims to analyze the effect of Shariah Complaints towards the profitability of Islamic Banks in Indonesia. This research is quantitative using documentation method and library study in data collection. The sampling technique uses purposive sampling with the criteria of Islamic commercial banks that publish annual-reports in 2013 to 2017 from 13 Islamic commercial banks (BUS) in Indonesia. The results of this study shows that the Funding and Investment, Products and Services, Employees, Community or Social, Environmental, Corporate Governance simultaneously does not have influence significantly the ROE variable, but it does significantly influence to ROA. Means that the wider the Islamic social reporting of an Islamic banking, the greater profitability of the Islamic banking. In addition, high profitability will encourage managers to provide more detailed information, because they want to convince investors of company profits and its compensation for management.
\end{abstract}

Keywords: Islamic Social Reporting, Equity, Profitability, Corporate Governance. 


\begin{abstract}
ABSTRAK
Perilaku kehati-hatian sangat penting dalam perusahaan, karena merupakan faktor yang menentukan keberlanjutan perusahaan seperti perbankan. Penelitian ini bertujuan untuk menganalisis pengaruh Pengaduan Syariah terhadap profitabilitas Bank Syariah di Indonesia. Penelitian ini adalah kuantitatif dengan menggunakan metode dokumentasi dan studi pustaka dalam pengumpulan data. Teknik pengambilan sampel menggunakan purposive sampling dengan kriteria bank umum syariah yang menerbitkan laporan tahunan pada 2013 hingga 2017 dari 13 bank umum syariah (BUS) di Indonesia. Hasil penelitian ini menunjukkan bahwa Pendanaan dan Investasi, Produk dan Layanan, Karyawan, Komunitas atau Sosial, Lingkungan, Tata Kelola Perusahaan secara bersamaan tidak memiliki pengaruh signifikan terhadap variabel ROE, tetapi itu berpengaruh signifikan terhadap ROA. Semakin luas Islamic social reporting suatu perbankan syariah, maka menunjukkan semakin besar profitabilitas pada perbankan syariah tersebut. Selain itu, profitabilitas yang tinggi akan mendorong manajer untuk memberikan informasi yang lebih rinci, karena mereka ingin meyakinkan investor tentang keuntungan perusahaan beserta kompensasinya untuk manajemen.
\end{abstract}

Kata Kunci: Pelaporan Sosial Islam, Ekuitas, Profitabilitas, Tata Kelola Perusahaan.

\title{
1. Pendahuluan
}

Dibalik perkembangnya perbankan syariah di Indonesia yang cukup pesat tersebut, ternyata masih terjadi perdebatan dikalangan masyarakat tentang kesyariahaan dari bank syariah. Selama ini masyarakat menilai bahwa bank syariah masih sama dengan dengan konvensional. Mu'alim dalam noven mengungkapkan bahwa beberapa ilmuan muslim ada yang mengencam bank syariah, mereka berpendapat bahwa bank-bank Islam dalam penyelenggarakan transaksi-transaksinya justru bertentangan dengan konsepnya, dengan kata lain bertentangan dengan prinsip-prinsip syariah. Hal tersebut disebabkan karena adanya ketidak sesuaian antara konsep dan praktik yang terjadi di bank syariah (Asmaul, 2015).

Isu lingkungan di Indonesia sedang hangat dibicarakan masyarakat pada akhir dekade ini, khususnya dampak yang disebabkan oleh kegiatan dari perusahaan. (Umiyati, 2018). Anggapan terhadap akuntansi Islam saat ini tentu masih banyak yang dipertanyakan orang, Hal ini sebenarnya merupakan hal yang wajar bila dikaitkan dengan batasan atau definisi yang dipakai serta pengetahuan ilmiah dari masing-masing pencetusnya. Namun lambat laun semua yang 
didahulunya masih dalam taraf konsep akhirnya muncul juga sebagai fenomena empiris seperti munculnya sebuah konsep akuntabilitas bebasis syariah, yaitu Islamic Social Reporting (ISR). ISR merupakan slah satu cara pengungkapan terhadap kondisi sebuah entitas perusahaan secara penuh dalam konteks Islam (Othman, 2009).

Transaksi syariah didasarkan pada paradigma bahwa Allah SWT menciptakan alam semesta sebagai amanah dan sarana kehidupan bagi seluruh umat manusia dalam mencapai kesejahteraan hakiki secara material dan spiritualc (al-falah) (kerangka Dasar Penyususnan dan Penyajian \pm Laporan Keuangan Syariah). Paradigma dasar ini menekankan setiap aktivitas umat manusia memiliki akuntabilitas dan nilai illahiah yang menepatkan perangkat Syariah dan akhlak sebagai parameter baik dan buruk, benar dan salahnya aktivitas usaha. Paradigma ini akan membentuk integritas yang membantu terbentuknya karakter tata kelola yang baik (good corporate) dan disiplin pasar (market discipline) yang baik (PSAK Syariah, 2017).

Perkembangan perbankan syariah di Indonesia dilihat dari segi indikator perkembangan aset bahwa aset perbankan syariah menunjukkan kecenderungan yang terus meningkat, dari Rp 7,9 triliun pada akhir Desember tahun 2003 meningkat menjadi Rp 14,2 triliun pada November tahun 2004 atau meningkat sebesar 339\%. Asset perbankan nasional hanya mengalami peningkatan sebesar 13,4\% dari 1062 triliun menjadi Rp. 1204 triliun pada periode yang sama. Perkembangan aset yang besar ini juga tidak lepas dari peningkatan jumlah kantor cabang bank syariah yang pesat pula seperti yang telah diuraikan di atas. Kontribusi aset perbankan syariah terhadap perbankan nasional masih sangat kecil. Namun, kontribusinya dari tahun ke tahun menunjukkan kecenderungan yang semakin meningkat. Sampai dengan posisi Oktober 2004 kontribusi perbankan syariah terhadap perbankan nasional telah mencapai 1.11\% (Sartika, 2016).

Promosi yang terlalu cepat menjadi proses pematangan karyawan yang tidak sebanding dengan pengalaman, kemampuan, keterampilan. Sebagai imbalannya, para pemilik bank menuntut prestasi kerja yang tinggi untuk memberikan keuntungan atas biaya besar yang telah dikeluarkannya. Hal ini menimbulkan tekanan kerja yang tinggi bagi karyawan perbankan sehingga sikap agresif dan terburu-buru yang cenderung mengabaikan aspek ketelitian dan kehati-hatian (Ikhsan, 2016).

Dalam UU No. 21 Tahun 2008 tentang Perbankan Syariah, Bank Syariah dan UUS dapat menajalankan fungsi sosial, yaitu menerima dana yang berasal dari zakat, infak, sedekah atau dana sosial lainnya dan menyalurkannya kepada pengelola wakaf (nazhir) sesuai kehendak pemberi peranan perbankan syariah dalam pemerataan kesejahteraan ekonomi umat. Beberapa penelitian yang telah dilakukan mengenai Islamic social reporting diantaranya Rosiana et.al (2015), Hasil penelitian menunjukkan bahwa ukuran perusahaan memiliki pengaruh 
signifikan terhadap pengungkapan pelaporan sosial Islam. Penelitian selanjutnya dilakukan oleh Ikhsan (2016), hasil penelitian menunjukkan bahwa secara proporsional hanya tiga variabel yang mempunyai pengaruh positif signifikan yaitu variabel tenaga kerja, sosial dan lingkungan. Terdapat dua variabel yang tidak mempunyai pengaruh secara signifikan terhadap nilai perusahaan bila dihitung secara parsial, yaitu variabel produk dan jasa serta tata kelola organisasi.

Penelitian dari Sugianto (2017) dan Nurlaila, mengungkapkan bahwa saat ini, bank syariah di Indonesia masih miskin dalam praktik pelaporan sosial. Dengan merujuk dari latar belakang masalah diatas, maka rumusan masalah dalam penelitian ini yaitu seberapa besar pengaruh Islamic Social Reporting secara persial dan simultan terhadap profitabilitas perbankan syariah pada Bank Umum Syariah di Indonesia.

\section{Tinjauan Pustaka}

\subsection{Legitimacy Theory}

Teori legitimasi sebagai suatu kondisi yang ada ketika suatu sistem nilai perusahaan yang sejalan dengan sistem nilai yang berlaku. Perusahaan menjalankan kegiatan sesuai dengan norma dan aturan yang berlaku. Menurut Suchman, menyebutkan (In'airat, 2015), "Legitimacy is a generalized perceptioner assumption that the actions o an entity are desirable, proper, or appropriate within some socially constructed system o norms, values, belies, anddeinitions".

Berdasarkan pengertian teori legitimasi di atas terdapat beberapa pengertian menurut para ilmuan lainnya, yaitu seperti Menurut Deegan, teori legitimacy mengungkapkan bahwa perusahaan secara continue berusaha untuk bertindak sesuai dengan batas-batas dan norma-norma dalam masyarakat. Atas usahanya tersebut perusahaan berusaha agar aktivitasnya diterima menurut persepsi pihak kesternal (Deegan, 2000). Menurut Rokhlinasari, Teori legitimasi menepatkan persepsi dan pengakuan publik sebagai dorongan utama dalam melakukan pengungkapan suatu informasi di dalam laoran keuangan (Rokhlinasari, 2015).

Berdasarkan pengertian diatas mengenai teori legitimasi menurut para ilmuan, maka terdapat beberapa kesimpulan bahwasanya teori legitimasi merupakan suatu kegiatan komunikasi atau berdialog dengan publik terkait dengan nilai sosial kemasyarakatan harus sesuai dengan persepsi sistem norma, nilai kepercayaan dan juga harus ada keselarasan dari nilai-nilai sosial untuk mendorong adanya pengungkapan suatu informasi didalam laporan keuangan.

\subsection{Stakeholder Theory}

Konsep tentang tanggung jawab sosial perusahaan telah mulai dikenal dengan stakeholder theory. Istilah stakeholder di perkenalkan pertama kali oleh Standord Research Institute (SRI) di tahun 1963 (Freeman, R. E. 1984). Menurut Freeman didefinisikan sebagai setiap kelompok atau individu dapat mempengaruhi atau dipengaruhi oleh operasi dan kegiatan perusahaan (Freeman, R. E. 2010).

Pengertian stakeholder dapat dijelaskan berdasarkan pengklasifikasiannya. Menurut Gray et all, Istilah stakeholder dar definisi menyatakan bahwa stakeholder adalah "pihak-pihak yang berkepentingan pada perusahaan yang 
dapat mempengaruh atau dapat dipengaruhi oleh aktivitas perusahaan, para stakeholder antara lain masyarakat, karyawan, pemerintah, supplier, pasar modal dan lain-lain." Dengan demikian, keberadaan suatu perusahaan sangat dipengaruhi oleh dukungan yang diberikan oleh stakeholder kepada perusahaan tersebut. Stakeholder theory berpandangan bahwa perusahaan harus melakukan pengungkapan sosial sebagai salah satu tanggung jawab kepada para stakeholder (Gray, Kouhy \& Lavers, 1995).

Selain itu menurut Eden dan Ackerman, menyatakan bahwa stakeholder yaitu orang atau kelompok yang memiliki kekuatan untuk secara langsung mempengaruhi masa depan organisasi, dengan tidak adanya kekuatan itu mereka tidak dianggap sebagai stakeholder (Eden \& Ackermann, 1998). Menurut R. Edward, stakeholder adalah individu atau kelompok yang dapat mempengaruhi atau dipengaruhi oleh tujuan organisasi (Edward, 1984). Stakeholder juga dapat didefinisikan sebagai individu dan konstituen yang memberikan kontribusi baik secara sukarela maupun terpaksa dalam menciptakan kapasitas dan aktivitas yang mengarah pada kemakmuran dan mereka mendapatkan keuntungan dan atau resiko karena aktivitas organisasi (Post, Preston \& Sach). Kepentingan seluruh stakeholder memiliki nilai intrinsik dan kepentingan-kepentingan tersebut tidak diarahkan untuk melakukan dominasi satu sama lain. Dengan demikian pengelola organisasi terutama organisasi bisnis harus menjamin bahwa hak-hak etis seluruh stakeholder diberikan perhatian secara seimbang sehingga tujuannya dalam memaksimalkan kemakmuran jangka panjang tercapai (Amaroh, 2016).

Dari beberapa penjelasan para ilmuan di atas mengenai stakeholder, maka dapat disimpulkan bahwa stakeholder merupakan sebuah kegiatan perusahaan seorang individu atau kelompok dalam organisasi tidak hanya untuk kepentingan perusahaan semata tetapi harus memberikan manfaat kepada masyarakat sekitar perusahaan.

\subsection{Profitabilitas}

Tujuan pokok penilaian kinerja adalah untuk memotivasi karyawan dalam mencapai sasaran organisasi dan dalam mematuhi standar perilaku yang telah ditetapkan sebelumnya, agar membuahkan tindakan dan hasil yang diharapkan. Standar perilaku dapat berupa kebajikan manajemen atau rencana formal yang dituangkan dalam anggaran (Febryani \& Zulfadin, 2003).

Profitabilitas adalah rasio yang paling kompehensif dari keseluruhan rasio yang ada dan rasio ini menggambarkan kemampuan bank untuk bertahan dan stabil dalam melanjutkan opeasionalnya di kemudian hari (Ferly et al, 2014). Sedangkan menurut Syafri, bahwa rasio profitabilitas merupakan rasio yang menggambarkan kemampuan perusahaan dalam mendapatkan laba melalui semua kemampuan dan sumber yang ada seperti kegiatan penjualan, kas, modal, jumlah karyawan, jumlah cabang dan sebagainya (Syafri, 2008). Menurut Jorenza, profitabilitas adalah kemampuan perusahaan dalam memperoleh laba dalam hubungannya dengan penjualan, total aktiva, maupun modal sendiri (Jorenza, 2015). Berbeda dengan Janggu yang berpendapat bahwa perusahaan dengan profitabilitas yang lebih tinggi kemungkinan akan mengungkapkan informasi yang lebih dibandingkan perusahaan dengan profitabilitas yang kurang (Janggu, 2004).

Profit dapat dihitung dangan menggunakan beberapa rasio, diantaranya Return On Equity dan Return On Asset. Rasio ini juga memberikan ukuran tingkat 
efektifitas manajemen suatu perusahaan. Indikator pengukuran profitabilitas dalam penelitian ini menggunakan ROE dan ROA. Return on Equity (ROE) adalah rasio yang digunakan untuk mengkaji sejauh mana suatu perusahaan mempergunakan sumber daya yang dimiliki untuk mempu memberikan laba ekuitas (Fahmi, 2012). Return On Asset adalah rasio yang menggambarkan kemampuan bank dalam mengelola dana yang diinvestasikan dalam keseluruhan aset yang menghasilkan keuntungan (Suwiknyo, 2016). Rasio profitabilitasini sekaligus menggambarkan efisiensi kinerja bank yang bersangkutan dikarenakan rasio ini mengutamakan nilai profitabilitas suatu bank yang diukur dengan aset produktif yang dananya sebagian besar berasal dari pihak ketiga (DPK). Jika semakin besar ROA suatu bank, maka semakin besar pula tingkat keuntungan yang dicapai bank tersebut dan semakin baik pula posisi bank tersebut dari segi penggunaan aset. Oleh Bank Indonesia, ROA diisyaratkan minimal 0,5\%.

\subsection{Islamic Social Reporting (ISR)}

ISR pertama kali dibahas oleh Ross Haniffa pada tahun 2002 dalam tulisannya yang berjudul "Social Reporting Disclosure: An Islamic Perspective". ISR lebih lanjut dikembangkan secara lebih ekstensif oleh Rohana Othman, Azlan Md Thani, dan Erlane K Ghani pada tahun 2009 di malaysia dan saat ini ISR masih terus di kembangkan oleh peneliti-peneliti selanjutnya. Menurut Haniffa, terdapat banyak keterbatasan dalam pelaporan sosial konvensional, sehingga ia mengemukakan kerangka konseptual ISR yang berdasarkan ketentuan syariah. ISR tidak hanya membantu pengambilan keputusan bagi pihak muslim melainkan juga untuk membantu perusahaan dalam melakukan pemenuhan kewajiban terhadap Allah dan masyarakat (Haniffa, \& Hudaib, 2002).

Menurut Haniffa dalam Rohana, Islamic Social Reporting adalah perpanjangan pelaporan sosial yang meliputi tidak hanya harapan dewan pengurus atas pandangan masyarakat terhadap peran perusahaan dalam ekonomi, tetapi juga memenuhi perspektif spiritual untuk pengguna laporan yang muslim (Rohana et al, 2009). Menurut Rohana et all, Islamic social reporting merupakan salah satu cara pengungkapan terhadap kondisi sebuah entitas perusahaan secara penuh dalam konteks Islami (Rohana et al, 2009).

Islamic Social Reporting merupakan standar pelaporan kinerja sosial perusahaan berbasis syariah.Islamic Social Reporting merupakan kerangka khusus untuk pelaporan pertanggungjawaban sosial yang sesuai dengan prinsip Islam. Tujuan dari Islamic Social Reporting sendiri adalah sebagai bentuk akuntabilitas perusahaan kepada Allah SWT dan masyarakat dan juga meningkatkan transparansi kegiatan bisnis dengan menyajikan informasi yang relevan dengan memperhatikan kebutuhan spiritual investor muslim atau kepatuhan syariah dalam pengambilan keputusan (Sutapa \& Laksito, 2018).

\subsection{Substansi Muatan Islamic Social Reporting}

Komponen pengungkapan ISR adalah item-item pengungkapan yang digunakan sebagai indikator dalam pelaporan kinerja sosial institusi bisnis syariah. Haniffa membuat lima tema pengungkapan indeks ISR, yaitu tema pendaan dan investasi, tema produk dan jasa, tema karyawan, tema masyarakat, dan tema lingkungan hidup. Kemudian dikembangkan oleh Othman et al., dengan 
menambahkan satu tema pengungkapan yaitu tema tata kelola perusahaan (Rohana et al, 2009).

\section{Metode Penelitian}

Jenis penelitian ini menggunakan pendekatan kuantitatif. Populasi dalam penelitian ini adalah seluruh Bank Umum Syariah yang ada di Indonesia. Data statistik per Desember menunjukkan bahwa Bank Umum Syariah di Indonesia berjumlah 13 BUS. Sampel yang diperleh berjumlah 9 bank umum syariah. Teknik pengambilan sampel yang digunakan yaitu purposive sampling dengan kriteria bank umum syariah yang mempublikasikan annual-report pada tahun 2013 sampai dengan 2017. Unit analisis dalam penelitian ini berjumlah 45 laporan tahunan Bank Umum Syariah. Metode pengumpulan data yang dilakukan untuk mengumpulkan data dalam penelitian ini adalah metode dokumentasi dan metode studi pustaka.

Variabel dependen pada penelitian ini profitabilitas yang mana diukur menggunakan Return On Asset dan Return On Equity, Profit dapat dihitung dangan menggunakan beberapa rasio, diantaranya Return On Equity dan Return On Asset. Rasio ini juga memberikan ukuran tingkat efektifitas manajemen suatu perusahaan. Indikator pengukuran profitabilitas dalam penelitian ini menggunakan ROE dan ROA. Variabel Independen yang dieksplorasi dalam analisis adalah Pendanaan dan Investasi, Produk dan Jasa, Karyawan, Masyarakat/Sosial, Lingkungan Hidup, dan Tatakelola Perusahaan. Untuk menunjang analisis isi tersebut adalah Melakukan scoring. Scoring dilakukan untuk mencari poin pengungkapan yang dinilai dengan 1 jika diungkapkan dan 0 jika tidak diungkapkan dari item pengungkapan yang telah dijabarkan dalam tabel indikator penelitian. Kemudian dari hasil uji checklist tersebut dilakukan perhitungan indeks. Indeks pengungkapan Islamic Social Reporting dihitung berdasarkan Berikut rumus untuk menghitung pengungkapan ISR, setelah pemberian nilai dilakukan

\section{Analisis dan Pembahasan}

Berdasarkan table 1 , diperoleh nilai signifikan sebesar $0,004<0,05$, sehingga HO diterima atau HA ditolak, maka dapat disimpulkan bahwa model regresi fit sehingga secara semultan islamic social reporting bersama-sama berpengaruh terhadap profitabilitas (ROA) bank umum syariah di indonesia. Karena secara keseluruhan pengungkapan islamic social reporting ini menunjukkan adanya pengungkapan terhadap kinerja keuangan pada suatu perusahaan. 
Tabel 1.1

Hasil Pengujian Simultan (Uji f)

ANOVA $^{\mathrm{a}}$

\begin{tabular}{|c|c|c|c|c|c|c|}
\hline \multicolumn{2}{|r|}{ Model } & \multirow{2}{*}{$\begin{array}{c}\begin{array}{c}\text { Sum of } \\
\text { Squares }\end{array} \\
164.250\end{array}$} & \multirow{2}{*}{$\begin{array}{c}\text { Df } \\
5\end{array}$} & \multirow{2}{*}{$\begin{array}{c}\text { Mean } \\
\text { Square } \\
32.850\end{array}$} & \multirow{2}{*}{$\begin{array}{c}\mathbf{F} \\
4.237\end{array}$} & \multirow{2}{*}{$\begin{array}{l}\text { Sig. } \\
.004^{\mathrm{b}}\end{array}$} \\
\hline 1 & Regression & & & & & \\
\hline & Residual & 302.367 & 39 & 7.753 & & \\
\hline & Total & 466.617 & 44 & & & \\
\hline
\end{tabular}

Sumber: Data diolah, 2019

Berdasarkan tabel 1.2 dapat diketahui bahwa variabel independen yaitu Islamic Social Reporting berpengaruh yang signifikan terhadap profitabilitas (ROA).

Tabel 1.2

Hasil Uji Parsial (Uji t)

Coefficients $^{\mathrm{a}}$

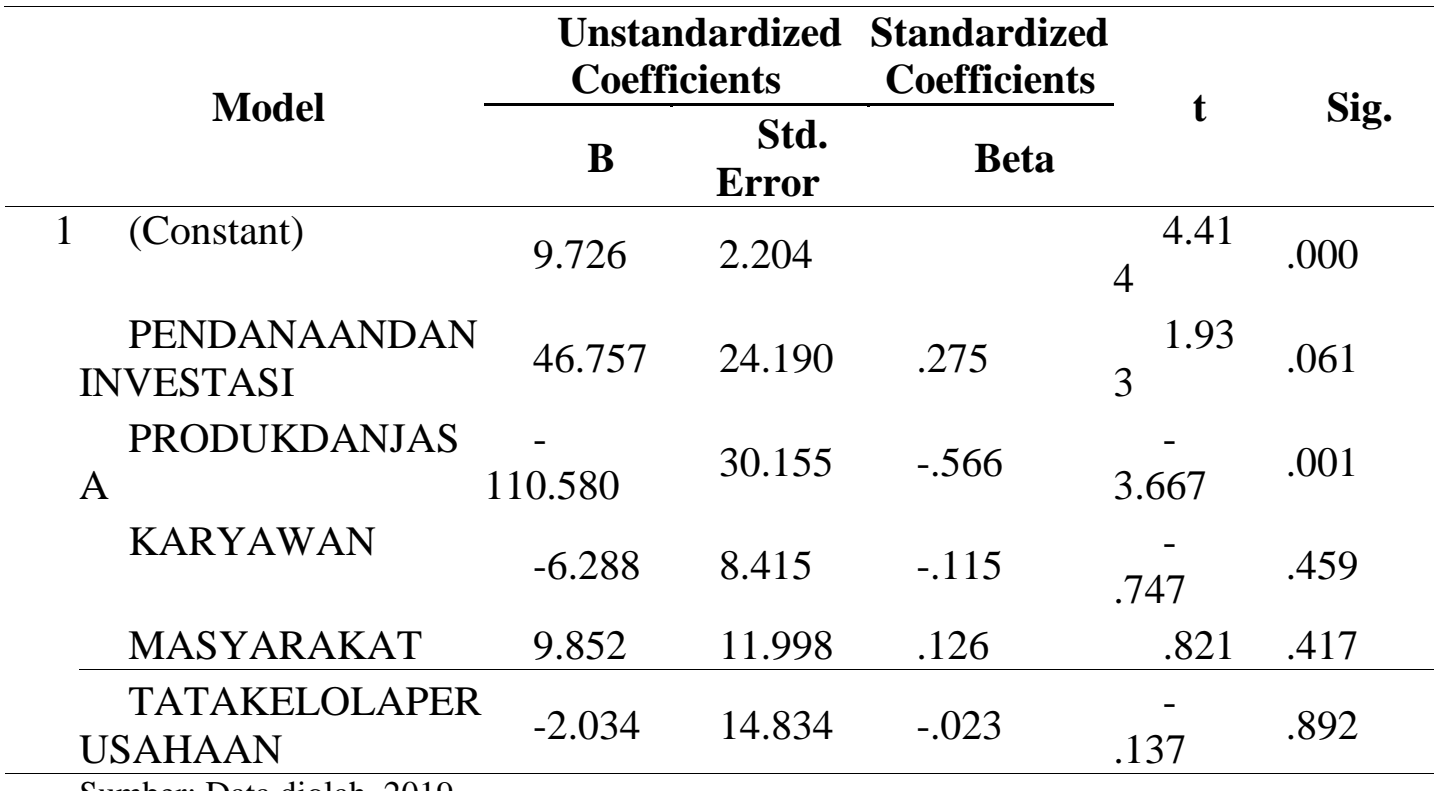

Sumber: Data diolah, 2019

Berdasarkan hasil perhitungan diketahui bahwa Pendanaan dan investasi mempunyai nilai signifikansi sebesar 0,061 lebih besar dari taraf 0,05 (0,048> 0,05). Oleh karena itu, dapat disimpulkan bahwa Pendanaan dan investasi tidak berpengaruh secara signifikan terhadap profitabilitas (ROA), maka H0 ditolak. Produk dan jasa mempunyai nilai signifikansi sebesar 0, 001 lebih kecil dari taraf $0,05(0,001<0,05)$. Oleh karena itu, dapat disimpulkan bahwa Produk dan jasa berpengaruh secara signifikan terhadap profitabilitas (ROA), maka $\mathrm{H} 1$ ditolak H0 diterima. Karyawan mempunyai nilai signifikansi sebesar 0,459 lebih besar dari taraf $0,05(0,459>0,05)$. Oleh karena itu, dapat disimpulkan bahwa karyawan tidak berpengaruh secara signifikan terhadap profitabilitas (ROA), maka H0 ditolak. Masyarakat/ sosial mempunyai nilai signifikansi sebesar 0, 417 lebih besar dari taraf $0,05(0,417>0,05)$. Oleh karena itu, dapat disimpulkan bahwa Maysarakat/sosial tidak berpengaruh secara signifikan terhadap profitabilitas 
(ROA), maka H0 ditolak. Tatakelola Perusahaan mempunyai nilai signifikansi sebesar 0,892lebih besar dari taraf 0,05 $(0,892>0,05)$. Oleh karena itu, dapat disimpulkan bahwa Tatakelola Perusahaan tidak berpengaruh secara signifikan terhadap profitabilitas (ROA), maka $\mathrm{H} 0$ ditolak.

Tabel 1.3

Hasil Koefisien Determinasi $\left(\mathbf{R}^{2}\right)$

Model Summary ${ }^{b}$

\begin{tabular}{cccccc}
\hline Model & $\mathbf{R}$ & $\begin{array}{c}\mathbf{R} \\
\text { Square }\end{array}$ & $\begin{array}{c}\text { Adjusted R } \\
\text { Square }\end{array}$ & $\begin{array}{c}\text { Std. Error of } \\
\text { the Estimate }\end{array}$ & $\begin{array}{c}\text { Durbin- } \\
\text { Watson }\end{array}$ \\
\hline 1 & $.593^{\mathrm{a}}$ & .352 & .269 & 2.78442 & 1.755 \\
\hline \multicolumn{4}{l}{ Sumber: Data diolah, 2019} \\
\end{tabular}

Berdasarkan tabel 1.3 diperoleh R-Square sebesar 0,352 yang berarti sebesar $35,2 \%$ nilai profitabilitas (ROA) dapat dijelaskan oleh komposisi variabel independen yaitu Islamic Social Reporting. Sedangkan 64,8\% dijelaskan oleh variabel diluar model penelitian.

Tabel 1.4

Hasil Uji Simultan (Uji f)

ANOVA $^{\mathrm{a}}$

\begin{tabular}{|c|c|c|c|c|c|c|}
\hline & Model & $\begin{array}{c}\text { Sum of } \\
\text { Squares }\end{array}$ & df & $\begin{array}{c}\text { Mean } \\
\text { Square }\end{array}$ & $\mathbf{F}$ & Sig. \\
\hline \multirow{3}{*}{1} & Regression & 388.029 & 5 & 77.606 & .944 & $.464^{b}$ \\
\hline & Residual & 3207.773 & 39 & 82.251 & & \\
\hline & Total & 3595.802 & 44 & & & \\
\hline
\end{tabular}

Berdasarkan tabel 1.4 di atas, diperoleh nilai signifikan sebesar 0,464 > 0,05, sehingga HO ditolak atau HA diterima, maka dapat disimpulkan bahwa model regresi fit sehingga secara semultan islamic social reporting secara bersama-sama tidak berpengaruh terhadap profitabilitas (ROE) bank umum syariah di indonesia. Karena pengungkapan Islamic Social Reporting pada suatu perusahaan perbankan syariah belum mengungkapkan secara keseluruhan terhadap kepatuhan tanggung jawab sosial terhadap kinerja keuangan perusahaan perbankan syariah. 
Tabel 1.5

Hasil Uji Persial (Uji t)

Coefficients $^{\mathrm{a}}$

\begin{tabular}{|c|c|c|c|c|c|c|}
\hline & \multirow[t]{2}{*}{ Model } & \multicolumn{2}{|c|}{$\begin{array}{c}\text { Unstandardized } \\
\text { Coefficients }\end{array}$} & \multirow{2}{*}{$\begin{array}{c}\begin{array}{c}\text { Standard } \\
\text { ized } \\
\text { Coefficie } \\
\text { nts }\end{array} \\
\text { Beta } \\
\end{array}$} & \multirow[t]{2}{*}{$\mathbf{t}$} & \multirow[t]{2}{*}{ Sig. } \\
\hline & & B & Std. Error & & & \\
\hline \multirow[t]{6}{*}{1} & (Constant) & 14.280 & 7.178 & & 1.990 & .054 \\
\hline & Pendanaandaninvestasi & 130.214 & 78.790 & .276 & 1.653 & .106 \\
\hline & Produkdanjasa & -64.633 & 98.220 & -.119 & -.658 & .514 \\
\hline & Karyawan & -36.772 & 27.409 & -.242 & 1.342 & .187 \\
\hline & Masyarakat & -6.318 & 39.079 & -.029 & -.162 & .872 \\
\hline & Tatakelolaperusahaan & 32.152 & 48.318 & .131 & .665 & .510 \\
\hline
\end{tabular}

Berdasarkan tabel 1.5 diketahui bahwa variabel independen yaitu Islamic Social Reporting tidak berpengaruh yang signifikan terhadap profitabilitas (ROE). Berdasarkan hasil perhitungan diketahui bahwa Pendanaan dan investasi mempunyai nilai signifikansi sebesar 0,106 lebih besar dari taraf $0,05(0,106>$ 0,05). Oleh karena itu, dapat disimpulkan bahwa Pendanaan dan investasi tidak berpengaruh secara signifikan terhadap profitabilitas (ROE), maka H0 ditolak. Produk dan jasa mempunyai nilai signifikansi sebesar 0,514 lebih kecil dari taraf $0,05(0,514>0,05)$. Oleh karena itu, dapat disimpulkan bahwa Produk dan jasa berpengaruh secara signifikan terhadap profitabilitas (ROE), maka H0 diterima HA ditolak. Karyawan mempunyai nilai signifikansi sebesar 0,187 lebih besar dari taraf $0,05(0,187>0,05)$. Oleh karena itu, dapat disimpulkan bahwa karyawan tidak berpengaruh secara signifikan terhadap profitabilitas (ROE), maka H0 ditolak. Maysarakat/ sosial mempunyai nilai signifikansi sebesar 0, 872lebih besar dari taraf $0,05(0,872>0,05)$. Oleh karena itu, dapat disimpulkan bahwa Maysarakat/sosial tidak berpengaruh secara signifikan terhadap profitabilitas (ROE), maka H0 ditolak. Tatakelola Perusahaan mempunyai nilai signifikansi sebesar 0,510lebih besar dari taraf 0,05 (0,510>0,05). Oleh karena itu, dapat disimpulkan bahwa Tatakelola Perusahaan tidak berpengaruh secara signifikan terhadap profitabilitas (ROE), maka H0 ditolak. 
Tabel 1.6

Hasil Koefisien Determinasi $\left(\mathbf{R}^{2}\right)$

Model Summary ${ }^{b}$

\begin{tabular}{cccccc}
\hline Model & $\mathbf{R}$ & $\begin{array}{c}\text { R } \\
\text { Square }\end{array}$ & $\begin{array}{c}\text { Adjusted } \\
\text { R Square }\end{array}$ & $\begin{array}{c}\text { Std. Error of the } \\
\text { Estimate }\end{array}$ & $\begin{array}{c}\text { Durbin- } \\
\text { Watson }\end{array}$ \\
\hline 1 & $\begin{array}{c}.328 \\
\mathrm{a}\end{array}$ & .108 & -.006 & 9.06921 & 1.639 \\
\hline \multicolumn{2}{l}{ Sumber: Data diolah, 2019} & &
\end{tabular}

Berdasarkan tabel diatas diperoleh R-Square sebesar 0,108 yang berarti sebesar 10,8\% nilai profitabilitas (ROE) dapat dijelaskan oleh komposisi variabel independen yaitu Islamic Social Reporting. Sedangkan 89,2\% dijelaskan oleh variabel diluar model penelitian.

Berdasarkan Uji F diketahui bahwa islamic social reporting yang terdiri dari Pendanaan dan Investasi, Produk dan Jasa, Karyawan, Masyarakat/Sosial, dan Tatakelola Masyarakat, secara semultan berpengaruh positif secara statistik terhadap Profitabilitas (ROA) bank umum syariah di indonesia. Akan tetapi secara semultan tidak berpengaruh positif secara statistik terhadap Profitabilitas (ROE) bank umum syariah di indonesia.

Hal ini sesuai dengan Freeman at al dalam Arif, teori stakeholder yang menyatakan bahwa perusahaan beroperasi bukan hanya untuk kepentingan perusahaan itu namun harus memberikan manfaat kepada stakeholder-nya. Apabila perusahaan dapat memaksimalkan manfaat yang diterima stakeholder maka akan timbul kepuasan dan apresiasi bagi stakeholder dan akan meningkatkan nilai perusahaan. Jika ditelaah secara persial terdapat satu indikator yang berpengaruh negatif signifikan dan terdapat satu indikator yang berpengaruh positif signifikan terhadap profitabilitas (ROA) bank umum syariah di indonesia, diantaranya:

Berdasarkan hasil perhitungan diketahui bahwa Produk dan jasa mempunyai nilai signifikansi sebesar 0 , 001 lebih kecil dari taraf $0,05(0,001<0,05)$. Oleh karena itu, dapat disimpulkan bahwa Produk dan jasa berpengaruh secara signifikan terhadap profitabilitas (ROA), maka H1 ditolak H0 diterima. Semakin luas Islamic social reporting suatu perbankan syariah, maka menunjukkan semakin besar profitabilitas pada perbankan syariah tersebut. Selain itu, profitabilitas yang tinggi akan mendorong manajer untuk memberikan informasi yang lebih terinci, karena mereka ingin menyakinkan investor terhadap keuntungan perusahaan serta kompensasi bagi pihak manajemen. Hasil penelitian ini sejalan dengan Lakharis yang membuktikan bahwa berpengaruh signifikan dalam pengungkapan dan mempunyai hubungan positif dengan kelengkapan pengungkapan ISR terhadap bank umum syariah, jadi semakin luas pengungkapan islamic social reporting suatu perusahaan maka semakin tinggi profitabilitas bank umum syariah. Sedangkan satu indikator dari Islamic Social reporting yang memiliki pengaruh signifikan terhadap nilai perusahaan telah menjalankan tanggung jawab sosial dengan baik. Seahingga mampu memberikan manfaat bagi stakeholder, maka akan timbul kepuasan dan apresiasi yang mempengaruhi meningkatkan profitabilitas bank umum syariah di indonesia.

Islamic Social Reporting terhadap ROE secara bersama-sama sebesar 0,464 lebih besar dari 0,05 maka hasilnya tidak fit, sehingga dapat kita ketahui ternyata 
Islamic Social reporting pada perusahaan bank syariah di Indonesia tidak memiliki pengaruh yang baik pada profitabilitas perbankan syariah. Hal ini dikarenakan banyak bank syariah di tahun 2017 yang menganggarkan dana tanggung jawab sosialnya cukup rendah khususnya pada karyawan, masyarakat sosial, serta tatakelola perusahaan yang tidak dapat membuktikan pengaruhnya di dalam hubungan ISR dan profitabilitas bank umum syariah di Indonesia. Tidak berpengaruhnya ISR terhadap ROE dapat dijelaskan karena para nasabah atau konsumen dalam memutuskan memilih bank syariah tidak melihat atatu menimbang pada ke syar'ian yang terindikasi pada ISR indeks pada bank yang dipilihnya dbandingkan dengan bank syariah lainnya. Hasil penelitian ini sejalan dengan Abi yang menyatakan bahwa pengungkapan islamic social reporting tidak menunjukkan signifikan pengaruhnya terhadap ROA. Begitu juga dengan penelitin Umi dkk, menunjukkan bahwa tidak ada pengaruh signifikan terhadap ROA dan ROE. Hal ini tidak sejalan dengan teori legitimasi karena ada beberapa perusahaan perbankan yang tidak mengungkapkan aktifitasnya ke publik, maka pihak bank perlu melakukan tindakan yang diinginkan, pantas, dan sesuai dengan sistem norma, nilai, kepercayaan dan definisi yang dikembangkan secara sosial. Selain itu hasil penelitian ini tidak sejalan dengan teori agensi yang mana hanya mementingkan nilai perusahaan akan tetapi harus ada manfaat untuk masyarakat sekitar perusahaan, semakin lemah posisi stakeholders, semakin kecil pula kecenderungan perusahaan mengadaptasi diri terhadap keinginan para stakeholdersnya. Akan tetapi sejalan dengan teori pengungkapan atas transaksi keuangan syariah yang mana Kontribusi aset perbankan syariah terhadap perbankan nasional masih sangat kecil.

Pada hasil penelitian ini diketahui ternyata semakin baik Islamic Social Reporting pada bank syariah di Indonesia akan berpengaruh meningkatnya profitabilitas pada bank umum syariah di Indonesia. Hal ini sejalan dengan teori legitimasi karena ada beberapa perusahaan perbankan yang mengungkapkan aktifitasnya ke publik, dan juga sejalan dengan teori stakeholder yang mana tidak hanya mementingkan nilai perusahaan akan tetapi harus ada manfaat untuk masyarakat sekitar perusahaan, semakin kuat posisi stakeholders, semakin besar pula kecenderungan perusahaan mengadaptasi diri terhadap keinginan para stakeholdersnya.

\section{Kesimpulan}

Penelitian ini dilakukan untuk menguji apakah Islamic Social Reporting memiliki pengaruh baik secara persial maupun secara simultan terhadap profitabilitas pada bank umum syariah tahun 2013-2017. Dari hasil pembahsan dapat diambil beberapa kesimpulan, sebagai berikut: pertama, Islamic Social Reporting yang terdiri dari pendanaan dan investasi, produk dan jasa, karyawan, Masyarakat/ sosial, Lingkungan Hidup, dan Tatakelola perusahaan secara persial terdapat satu indikator produk dan jasa yang berpengaruh secara signifikan terhadap profitabilitas (ROA) bank umum syariah di Indonesia. Berdasarkan indikator yang berpengaruh tersebut dalam kepatuhan pihak bank bagus dalam memasarkan produk-produknya kepada stakeholder sehingga profit perbankan meningkat dengan baik. Kedua, secara simultan Islamic social reporting tidak 
berpengaruh secara signifikan terhadap profitabilitas (ROE) bank umum syariah. Akan tetapi islamic social reporting berpengaruh secara signifikan terhadap profitabilitas (ROA) bank umum syariah di Indonesia. Berdasarkan adanya pengaruh tersebut pihak bank perlu memfokuskan pada ISR.

\section{Daftar Pustaka}

Anita Febryani Dan Rahadian Zulfadin (2003). Analisis Kinerja Bank Devisa Dan Bank Non Devisa Di Indonesia. Jurnal Kajian Ekonomi Dan Keuangan. 7(4), 2003.

B. Maali, P. Cassonand C Napier, 2006. "Social Reporting By Islamic Banks", Abacus, 42(2).

Deegan, C. (2000). Financial Accounting Theory. NSW: Mc Graw-Hill Australia.

Suwiknyo, Dwi. Analisis Laporan Keuangan Perbankan Syariah. Yogyakara: Pustaka.

Eden, C. \& Ackermann, F. (1998). Making Strategy: The Journey of Strategic Management. Sage Publications, London.

Ferly Ferdyant, Ratna Anggraini Zr, Erika Takidah. "Pengaruh Kualitas Penerapan Good Corporate Governance Dan Risiko Pembiayaan Terhadap Profitabilitas Perbankan Syariah”. Jurnal Dinamika Akuntansi Dan Bisnis. 1(2), September 2014.

Freeman, R. E. 1984. Strategic Management: A Stakeholder Approach. Pitman Publishing, Boston.

Gray, R, Kouhy, R. and Lavers, S. (1995), “Corporate Social And Environmental Reporting: A Review Of The Literature And A Longitudinal Study Of Uk Disclosure", Accounting, Auditing \& Accountability Journal, Vol. 8(2), 4777.

Haniffa, R.M. and Hudaib, M.A. (2002), "A Conceptual Framework for Islamic Accounting: The Shari" a Paradigm", paper presented at the Accounting, Commerce \& Finance: The Islamic Perspective International Conference IV, New Zealand

Imam Abi al-Husain Muslim bin al-Hajjaj al-Qusyairi an-Naisaburiy. 1995. Shahih Muslim. J.5. Beirut: Dar al-Kitab al- Imaniyah.

In'airat, M. 2015. The Role of Corporate Governance in Fraud Reduction- A Perception Study in the Saudi Arabia Business Environment. Journal of Accounting and Finance, 15 (2), 119.

Irham Fahmi, Pengantar Pasar Modal (Bandung: Alfabeta, 2012), h. 98.

J. E., Post, L. E. Preston, Dan S. Sach, "Managing The Extended Entreprise: The New Stakeholder View”, California Management Review, Vol. 45, (2002).

Janggu, T., (2004). Corporate Social Disclosure of Construction Companies In Malaysia, Master Thesis. Universiti Teknologi Mara.

Jorenza Chiquita Sumanti (2015) meneliti Analisis Kepemilikan manajerial, Kebijakan hutang dan Profitabilitas terhadap Kebijakan dividen dan nilai perusahaan pada Perusahaan Manufaktur yang terdaftar di BEI

M.Ikhsan P. "Pengaruh Islamic Social Reporting Terhadap Nilai Perusahaan Bank Syariah Di Indonesia”. Tesis. 
Mila Sartika, Hendri Hermawan A, "Implementasi Ijarah Dan Imbt Pada Bank Bri Syariah Cabang Yogyakarta". Vol.Vii(1). Mei 2016

R. Edward Freeman, Strategic Management: A Stakeholder Approach. Boston: Pitman Press, 1984.

Rohana Othman, A. Md. Thani, dan dan E.K. Ghani, "Determinants of Islamic Social Reporting Among Top Shariah-Approved Companies in Bursa Malaysia”, Research Journal of International Studies, Vol. 12, 2009.

Rokhlinasari, Sri (2015). Teori-Teori Dalam Pengungkapan Informasi Corporate Social Responbility Perbankan. Al-Amwal: JurnalKajian Ekonomi Dan Perbankan Syariah,7(1), 1-11.

Septi Widiawati, Raharja, Surya. (2012). Analisis Faktor-Faktor Yang Mempengaruhi Islamic Social Reporting Perusahaan-Perusahaan Yang Terdapat Pada Daftar Efek Syariah Tahun 2009-2011. Journal Of Accounting. 1(2), 1-15.

Siti Amaroh. "Tanggung Jawab Sosial Bank syariah terhadap stakeholder dalam perspekti maqashid syariah”. Ahkam: Vol. Xvi(1), Januari 2016.

Siti Asmaul Usnah, Noven Suprayogi. "Pandangan Mahasiswa Fakultas Ekonomi Dan Bisnis Universitas Air langga Tentang Kepatuhan Syariah Di Bank Syariah”. Jurnal JESTT. 2(2) Februari 2015.

Soyan syarif Harahap. 2007. Analisis Kritis atas Laporan Keuangan. Jakarta: Raja Graindo Persaja.

Syamsuddin, Lukman. 2007. Manajemen Keuangan Perusahaan. Jakarta. PT Raja Grafindo Persada. 